\title{
Prize Awards for 1936 of the Paris Academy of Sciences
}

$\mathrm{A}$ $T$ the annual public meeting of the Academy of Sciences held on December 21, 1936, the prizes and awards for the year 1936 were announced as follows :

Mathematics.-The Poncelet Prize to Paul Lévy, for the whole of his mathematical works; the Francœur Prize to Claude Chevalley, for his work on the theory of bodies of classes.

Mechanics.--The Montyon Prize to Louis Bergeron, for his work on hydraulic machines; the Fourneyron Prize to André Tenot, for his work on hydraulic turbines; the Boileau Prize to Max Teissié-Solier, for his hydraulic researches on the natural turbulent regime; the Henri de Parville Prize to Henri Poncin, for his work in hydrodynamics.

Astronomy.-The Lalande Prize to Louis Boyer, for his work on the minor planets; the Benjamin Valz Prize to André Couder, for his work on optical instruments; the Janssen Medal to Henry Norris Russell, for his important work on stellàr astronomy.

Geography. - The Delalande Prize to Jean Rothe, for his observations and researches on the physies of the globe and physical geography carried out in Greenland (Scoresby Sound); the Gay Prize to the Institut scientifique chérifien, for work on the natural resources of Morocco; the Binoux Prize to Edouard de Martonne, for the whole of his work on colonial cartography.

Navigation.-The Prix de la Marine to René Perrin, for his studies on the working of self-propelled torpedoes; the Plumey Prize to René Norguet, for his studies on marine boilers.

Physics.-The L. La Caze Prize to Jean Becquerel, for the whole of his work in magneto-optics; the François Hébert Prize to Georges Albert Boutry, for his researches on photo-electric cells and their applications; the Hughes Prize to Marcel Laporte, for his researches on the electric discharge in gases; the Paul Marguerite de la Charlonie Prize to Henri Abraham, for the whole of his scientific work; the Clément Félix Foundation to Mlle. Nine Choucroun, for the continuation of her work on electrophoresis.

Chemistry.-The Montyon Prize (Unhealthy Trades) to Paul de Graeve, for his work on phosgene; an honourable mention (1,500 francs) to Jean Le Bras, for his contribution to the study of the extinguishing powers of various materials on flames; the Jecker Prize to Charles Dufraisse, for his work in organic chemistry; the L. La Caze Prize to Paul Job, for his work on inorganic complex compounds and on the application of physical methods to chemistry; the Cahours Foundation to Arthur Brunel, for his researches on fungi ; the Houzeau Prize to Maurice Rangier, for his work on uric acid and its complex compounds; the Charles Adam Girard Prize to Georges Kravtzoff, for his work on the electrolysis of organic salts of copper.

Mineralogy and Geology.-The Cuvier Prize to Emile Félix Gautier, for his work on the physical geography of Madagascar and the Sahara; the Victor Raulin Prize to Henri Longchambon, for his researches on clays.

Botany.-The Desmaziòres Prize to Camille Sauvageau, for his work entitled "Sur quelques algues phéosporées de Guéthary"; the Montagne Prize between Germain Chalaud, for his work "Groupe de Cryptogames : les Hepatiques", and Jean Chaze, for his work on the culture of the Saprolegniæe and the diseases of cultivated mushrooms; the De Coincy Prize to Désiré Bois, for the whole of his work.

Rural Economy. - The Demolombe Prize to Félicien Bouf, for his work entitled "Les bases scientifiques de l'amélioration des plants".

Anatomy and Zoology.-The Da Gama Machado Prize to Pierre Cappe de Baillon, for his work on phasmid insects ; the Savigny Foundation to René Dieuzeide, for his work on the Algerian coastal fauna and their parasites ; the Jean Thore Prize to Gaston Portevin, for his book on the natural history of French Coleoptera.

Medicine and Surgery.-The Montyon Prize between Léon Delhoume (2,500 francs), for his book entitled "Dupuytren", Marius Piéry (2,500 franes), for his book on biological and medical climatology, and Pierre Rigaud (2,500 francs), for his book entitled "Le labyrinthe, étude physio-pathologique et clinique"; honourable mentions (1,500 franes) to Jacques Courtois and Raoul Lecoq, for their work on puerperal infections, and to André Feil, for his book entitled "Le travail de l'ardoise et la pathologie professionalle de l'ardoisier"; a mention (1,500 francs) to Maurice Sourdille, for his book "Traitement chirurgical de l'otospongiose"; citations to Emile Gilbrin and to Georges Fabiani ; the Barbier Prize to Bernard Gouzon, for his book "Sur l'etude de quelques Porphyrines naturelles. Application aux pigments fluorescents de l'œuf des oiseaux"; the Bréant Prize to Jean Laigret, for his work on yellow fever and preparation of the vaccine; the Godard Prize to Pierre Feyel, for his book "Le tube urinaire dans le série animale"; the Mège Prize to Joseph Magrou, for his memoir on the scientific work of Maurice Nicolle; the Bellion Prize to Marcel Belin, for his book "Coquillages et fièvres typhoïdes" ; the Baron Larrey Prize to Pierre Oudard, for his memoir on the organization and working of the health service of the navy at sea in time of war; the Charles Bouchard Prize to Mario Lebel, for his work on traumatisms of the liver; the Jean Dagnan-Bouveret Prize to Claudius Regaud, for the whole of his researches in histophysiology and in normal and pathological radiophysiology.

Cancer and Tuberculosis.-The Roy-Vaucouloux Foundation to Léon Velluz, for his work on experimental production of cancer with polycyclic hydrocarbons; the Louise Darracq Prize to Charles Oberling and Maurice Guérin, for their work on the production of tumours by means of transmissible leucæmia of fowls; the Eugène and Amélie Dupuis Prize to Ernest Coulaud, for the whole of his work on tuberculosis.

Physiology.-The Montyon Prize to Georges Vanhems, for his work on the biochemistry of potassium ; the L. La Caze Prize to Charles Dhéré, for his physiological work especially on the spectrography of biological materials; the Pourat Prize to Roger Gautheret, for his memoir on the culture of plants, and attempts at the culture of meristematic tissues ; the Martin-Damourette Prize to Daniel Bovet, for his pharmacological researches especially on the derivatives of aminomethylbenzodioxan. 
Statistics.-The Montyon Prize to Michel Huber, for the whole of his work in statistics.

History and Philosophy of Science.--The Binoux Prize between Paul Nève de Mévergnies (2,000 francs), for his memoir on Jean Baptiste van Helmont, and Charles Cabanes (1,500 franes), for his work on Denys Papin.

Works of Science.-The Henri de Parville Prize between Georges Bruhat (3,000 francs), for his book on thermodynamics, electricity, optics and physical mechanics, Guillaume Grandidier (2,000 francs), for his atlas of the French colonies, protectorates and territories under French mandate, and Pierre Gauja (2,000 francs), for his study on "L'Académie des Sciences de l'Institut de France".

Medals. - The Berthelot Medal to Paul de Graeve, Paul Job and Maurice Rangier.

General Prizes.-Prize founded by the State (mathematical sciences) to Maurice Gevrey, for his work on partial differential equations; the Bordin Prize to Henri Termier, for his important geological studies on central Morocco and the northern MoyenAtlas ; the Lallemand Prize to Ivan Bertrand, for his memoir on micrography in infra-red light and its application to renal cytology; the Vaillant Prize to Père Lejay, for his researches on the determination of gravity in the Far East; the Le Conte Prize to the late Julien Costantin, for the whole of his work; the Jean Reynaud Prize to Alfred Lacroix, for the whole of his scientific work; the Baron de Joest Prize to Paul Robert, for his researches on anallagmatic geometry and its relations with projective geometry; the Houllevigue Prize to Etienne Wolff, for his researches in experimental embryogeny and teratogenesis; the Parkin Prize $(2,400$ francs) to
Jean Jacques Bouckaert and Fernand Jourdan, for their work on the pharmacodynamics of the cerebral vessels ; an encouragement (1,000 francs) to Bernard Ménétrel, for his memoir on intravenous activated carbon in therapeutics; the Saintour prize to Robert Weill, for his work entitled "Contribution à l'étude des Cnidaires et de leur nématocystes" ; the Lonchampt Prize to Paul Meunier, for his researches on aluminium in animals; the Henri Wilde Prize to Georges Dupont, for the whole of his chemical work; the Caméré Prize to Lucien Chadenson, for his work in hydraulics; the Gustave Roux Prize to Henri Erhart, for his treatise on pedology; the Thorlet Prize to Paul Dorveaux; the Albert I of Monaco Prize to Fernand Holweck, for his work on the Holweck-Lejay pendulum; the Marquet Prize to Gustave Ribaud, for his researches on high tempera. tures ; the Alexandre Darrasq Prize to Etienne Audibert, Ferdinand Vallette and Francis Michot-Dupont (20,000 francs each), for methods of preparing petrol and benzene from materials obtained in France.

Prizes of the Grandes Ecoles.-The Laplace Prize to Robert Gachet; the L. E. Rivot Prize between Robert Gachet, Paul Cusset, Charles Mallet and Albert Jouvent.

General Foundations for Scientific Research.-The Gegner Foundation to the late Maurice Parat, for his work on the physiology of the cell; the Jérôme Ponti Foundation to Henri Besairie, for his work on the geology of Madagascar; the Hirn Foundation to Albert Arnulf, for his work in applied optics; the Henri Becquerel Foundation to Carl Benedicks, for his discoveries on the homogeneous thermoelectric effect.

(To be continued.)

\section{Progressive Teaching in Geography}

\section{The Geographical Association}

$\mathrm{T}$ HE Annual Conference of the Geographical Association was held at the London School of Fconomics on January 5-7.

At the first lecture meeting, Dr. L. Dudley Stamp dealt with Portugal in 1936 and entered a plea for geographers to accord separate consideration to Spain and Portugal rather than to group the two together, which they frequently do, as the Iberian Peninsula. The cultural background and history so clearly demarcate the two that the visitor cannot help being struck by the differences, which indeed recent events have emphasized. By means of lantern slides the remarkable changes witnessed in a traverse from north to south were demonstrated, and a tentative division of the country was suggested into the north-west, the north-east, the middle Douro basin (the port-wine area), the coastal belt, north centre, south centre (these two separated by the Tagus), the southern Sierra, and the Algarve.

On January 6, Sir William Beveridge took the chair at an important symposium on "Whither Population?" in which Prof. C. B. Fawcett stressed the spatial distribution of the world's population, and Dr. R. R. Kuczynski the changing distribution in time. Prof. Fawcett demonstrated that modern development and migration are not filling up the empty spaces of the world but, on the contrary, the great cities are increasing relatively to the whole and the pioneer fringe is moving back. Even in densely populated Great Britain, rural depopulation has been in progress for many decades, and one-fifth of the land surface has more than fifty-eight per cent of the people (compared with fifty-one per cent ten years ago). In Canada, forty-two per cent of the people live on less than one per cent of the land; in the United States, more than fifty per cent on less than two per cent; in Australia, more than fifty per cent in the capital cities alone. Dr. Kuczynski developed his now well-known theory of population increasethat the true measure is the relation between women of child-bearing age and births of female childrenbetween the mothers of to-day and the mothers of to-morrow. Where this net reproduction-rate falls below 1, the population must decrease. It is actually below 1 in all the countries of northern and western Furope, except the Irish Free State and Poland. It reaches its highest European figure now in the U.S.S.R. (more than 1.2). In Japan it is about $1 \cdot 4$. At present in Great Britain it is about $0 \cdot 75$, represent. ing a decrease of one per cent per annum. The population at this rate will fall bolow 30 million by 2000 A.D. and below 20 million in 2036. As Sir 